\title{
Effect of hydrocolloids on potential availability of calcium
}

\author{
J Marin, JA Zee *, R Kouaouci \\ Département de nutrition humaine et consommation, Université Laval, \\ Sainte-Foy, Québec, Canada, G1K 7P4
}

(Received 11 December 1989; accepted 6 August 1990)

\begin{abstract}
Summary - Interactions between calcium ions and hydrocolloids (kappa-carrageenan, sodium alginate, pectin, carboxymethylcellulose, locust bean gum, guar gum and gelatin) were evaluated at different $\mathrm{pH}$ levels $(1,4,7$ and sequential $1-7)$. Only kappa-carrageenan and alginate were found to bind appreciable amounts of $\mathrm{Ca}$ ions at $\mathrm{pH} 4$ and 7 because of their anionic character. However, in the case of alginate, the affinity to bind $\mathrm{Ca}^{2+}$ decreased with increase of this hydrocolloid concentration at $\mathrm{pH} 7$. In addition, when the $\mathrm{pH}$ was sequentially increased from 1 to 7 , kappa-carrageenan did not bind $\mathrm{Ca}^{2+}$ as compared to sodium alginate. On the other hand, charged hydrocolloids (pectin and carboxymethylcellulose) as well as neutral hydrocolloids (locust bean gum, guar gum and gelatin) have little or no ability to interact with calcium under the various conditions studied.
\end{abstract}

\section{calcium / hydrocolloid / interaction / pH / potential bioavailability / solubility}

Résumé - L'effet des hydrocolloïdes sur la disponibilité potentielle du calcium. Les interactions entre le calcium et certains hydrocolloïdes (kappa-carraghénane, alginate de sodium, pectine, carboxyméthylcellulose, gomme de caroube, gomme guar et gélatine) ont été étudiées à différents $\mathrm{pH}(1,4,7$ et séquentiel 1 à 7$)$. De tous ces hydrocolloïdes seuls le kappa-carraghénane et l'alginate montrent une forte affinité vis-à-vis des ions $\mathrm{Ca}$ aux $\mathrm{pH} 4$ et 7 à cause de leur caractère anionique. Cependant, cette affinité diminue à $\mathrm{pH} 7$, dans le cas de l'alginate, avec l'augmentation de la concentration en ce polymère. D'autre part, après traitement séquentiel du $\mathrm{pH}$, le carraghénane perd la capacité de fixer les ions $\mathrm{Ca}^{2+}$ comparativement à l'alginate. Quant aux autres hydrocolloïdes anioniques (pectine et carboxyméthylcellulose) et neutres (gomme de caroube, gomme de guar et gélatine), ils ne montrent que très peu ou presque pas d'affinité pour le calcium dans les conditions étudiées.

calcium / hydrocollö̈de / interaction / pH / disponibilité potentielle / solubilité

\footnotetext{
* Correspondence and reprints
} 


\section{INTRODUCTION}

During the last two decades, interest has focussed on the role of calcium in the prevention of diseases such as osteoporosis and hypertension (Albanese, 1977; McCarron, 1985). Several studies have postulated a relationship between osteoporosis and life-long low calcium intakes (Matkovic et al, 1979; Sowers et al, 1985).

The recommended daily allowance (RDA) for calcium is presently $800 \mathrm{mg}$ for adults, but more than $1200 \mathrm{mg} \mathrm{Ca}$ per day has been suggested for premenopausal women (Heaney, 1982). To achieve an adequate $\mathrm{Ca}$ intake, increased consumption of milk and dairy products has been recommended.

The absorption of calcium is influenced not only by physiological factors such as pregnancy, growth and lactation, but also by dietary components such as hydrocolloids whose thickening and gelling properties are widely exploited particularly in the dairy industry (Allen, 1982; Rizzotti et al, 1983). The presence of these substances in food products appears to affect the availability of mineral nutrients in general. The information presently available, however, is scant.

Recent in vitro studies have shown that mineral solubility under physiological $\mathrm{pH}$ conditions of gastrointestinal system is a good indicator of their bioavailability (Miller et al, 1981; Zemel, 1984; Wien and Schwartz, 1985). For example, both soluble and ionic calcium levels provide a satisfactory qualitative indication of $\mathrm{Ca}$ availability in foodstuffs (Kim and Zemel, 1986).

Several authors have also observed that certain hydrocolloids may affect the absorption of essential minerals. HarmuthHoene and Schelenz (1980) showed that both carrageenan and agar-agar depressed $\mathrm{Ca}$ absorption in rats while neither sodium alginate nor guar gum did. The results of in vivo studies with alginate are thus far contradictory, showing interference with $\mathrm{Ca}$ absorption in some cases (Hodgkinson et al, 1967; Viola et al, 1970), while in others no effect has been observed (Millis and Reed, 1947; Carr et al, 1968). Low methoxylated pectin has been found to depress drastically the absorption and retention of $\mathrm{Ca}, \mathrm{Mg}$ and $\mathrm{Zn}$ by the growing pig (Bagheri and Guéguen, 1985). Berner and Hood (1983) reported that sodium alginate preferentially bound $\mathrm{Ca}$ in the presence of iron and that alginate-iron complexes were disrupted during digestion. Locust bean gum and guar gum have been found to reduce zinc and iron solubility and hence their availability (Zemel and Zemel, 1985), while Camire and Clydesdale (1981) reported that pectin (low methoxylated) in aqueous solution bound more $\mathrm{Ca}$ than guar gum did.

The purpose of this study is to examine the effect of some hydrocolloids such as kappa carrageenan, gelatin, guar gum, pectin, sodium alginate, carboxymethylcellulose (CMC) and locust bean gum on calcium solubility under different $\mathrm{pH}$ conditions.

\section{MATERIAL AND METHODS}

Gelatin (Type B, from bovine skin), pectin (7.7\% methoxylated), carboxymethylcellulose (sodium salt, medium viscosity), locust bean gum, kappa carrageenan (sodium salt), alginic acid (sodium salt), calcium chloride $\left(\mathrm{CaCl}_{2} \cdot 2 \mathrm{H}_{2} \mathrm{O}\right)$ and lanthanum chloride $\left(\mathrm{LaCl}_{3} \cdot 7 \mathrm{H}_{2} \mathrm{O}\right)$ were purchased from Sigma Chemical Co, St Louis, MO. Guar gum was obtained from ICN Biochemicals, Cleveland, $\mathrm{OH}$.

Ca-hydrocolloid mixtures were prepared by dissolving $0.2 \mathrm{~g}(0.2 \%)$ or $0.4 \mathrm{~g}(0.4 \%)$ of hydrocolloid in $80 \mathrm{ml}$ distilled and deionized water, adjusting the $\mathrm{pH}$ to 1.4 , or 7 with $0.1 \mathrm{~N} \mathrm{HCl}$ or 0.1 $\mathrm{N} \mathrm{NaOH}$, and adding calcium chloride solution $(32.3 \mathrm{mg}$ ) before bringing the volume to $100 \mathrm{ml}$. 
They were incubated for $2 \mathrm{~h}$ at $37^{\circ} \mathrm{C}$ in a shaker-bath. For sequential treatments, hydrocolloid solutions containing $\mathrm{Ca}$ were incubated at $\mathrm{pH} 1$ for $2 \mathrm{~h}$ at $37^{\circ} \mathrm{C}$. The samples were then brought to $\mathrm{pH} 4$, incubated for $1 \mathrm{~h}$ and $37^{\circ} \mathrm{C}$ and finally the $\mathrm{pH}$ was raised to 7 and samples were incubated for one additional hour at the same temperature. For each $\mathrm{pH}$ treatment, standards containing only $\mathrm{Ca}$ were prepared according to the same procedure described above. To suppress phosphate interference, $0.5 \mathrm{~g}$ lanthanum was added to each sample. Total $\mathrm{Ca}$ was determined by digesting duplicate aliquots $(10 \mathrm{ml})$ of each sample in $12 \mathrm{ml}$ of $\mathrm{HNO}_{3}-\mathrm{HClO}_{4}(3: 1)$ in Kjeldahl flasks for $\mathbf{4 5} \mathrm{min}$, analysing by atomic absorption spectrometry (AAS) (Instrumentation Laboratory Spectophotometer, model IL751, Wilminton, MA). The remainder $(80 \mathrm{ml})$ of the incubated sample was then centrifuged at $27000 \mathrm{~g}$ for $1 \mathrm{~h}$ at $5^{\circ} \mathrm{C}$ and the supernatant filtered on ashless Whatman \#1. Ten $\mathrm{ml}$ duplicate aliquots of the filtered supernatant were digested and analysed for soluble $\mathrm{Ca}$ by AAS as described above. Two other $10 \mathrm{ml}$ aliquots were brought to $100-\mathrm{ml}$ with deionized water. To each of these were added $2 \mathrm{ml} 4 \mathrm{M} \mathrm{KCl}$ solution for ionic calcium measurement using a $\mathrm{Ca}$ ion-selective electrode (Model 93-21, Orion Research Inc, Cambridge, MA). Analyses were performed in duplicate throughout the experiment. All data were analyzed by analysis of variance, and Duncan's Multiple Range test was used to separate significantly different group means (SAS, 1986).

\section{RESULTS AND DISCUSSION}

Results obtained with $0.2 \%$ (w/v) hydrocolloid in the presence of calcium at three

Table I. Effects of $0.2 \%$ hydrocolloid solutions on soluble and ionic calcium at three $\mathrm{pH}$ levels. ${ }^{1}$ Total calcium; ${ }^{2}$ soluble calcium; ${ }^{3}$ ionic calcium; ${ }^{4}$ carboxymethylcellulose; ${ }^{5}$ locust bean gum; ${ }^{6} \mathrm{CaCl}_{2}$ without gum; ${ }^{a-f}$ different letters in superscript denote significant differences in each column $(P<0.05)$.

Effets de solutions d'hydrocolloides à $0,2 \%$ sur les teneurs en calcium soluble et ionique à trois niveaux de $\mathrm{pH}$.

\begin{tabular}{|c|c|c|c|c|c|c|c|c|c|}
\hline \multirow[b]{2}{*}{ Hydrocolloids } & \multicolumn{3}{|c|}{$p H 1$} & \multicolumn{3}{|c|}{$\mathrm{pH} 4$} & \multicolumn{3}{|c|}{$\mathrm{pH} 7$} \\
\hline & $C a_{\text {tot }}{ }^{1}$ & $\begin{array}{l}\mathrm{Ca}_{\text {so }}{ }^{2} \\
(\mathrm{ppm})\end{array}$ & $C a_{i o n}{ }^{3}$ & $C a_{\text {tot }}$ & $\begin{array}{l}C a_{\text {sol }} \\
(p p m)\end{array}$ & $C a_{\text {ion }}$ & $C a_{\text {tot }}$ & $\begin{array}{l}C a_{\text {sol }} \\
(\mathrm{ppm})\end{array}$ & $C a_{\text {ion }}$ \\
\hline \multirow[t]{2}{*}{ K-carrageenan } & 11.50 & 11.30 & 11.33 & 12.50 & 8.60 & 8.75 & 11.35 & 7.13 & 7.13 \\
\hline & $\pm 0.08^{b c}$ & $\pm 0.09 \mathrm{c}$ & $\pm 0.08^{b c}$ & $\pm 0.06^{a}$ & $\pm 0.00^{\circ}$ & $\pm 0.14^{\theta}$ & $\pm 0.09^{c d}$ & $\pm 0.10^{\circ}$ & $\pm 0.11^{d}$ \\
\hline \multirow[t]{2}{*}{ Alginate } & 11.23 & 11.20 & 11.33 & 12.72 & 6.22 & 6.32 & 12.82 & 3.52 & 2.62 \\
\hline & $\pm 0.08^{\mathrm{cd}}$ & $\pm 0.09 \mathrm{~cd}$ & $\pm 0.08 \mathrm{bc}$ & $\pm 0.05^{a}$ & $\pm 0.29^{f}$ & $\pm 0.13^{f}$ & $\pm 0.09^{a}$ & $\pm 0.19^{f}$ & $\pm 0.03^{\circ}$ \\
\hline \multirow[t]{2}{*}{ Pectin } & 11.80 & 11.85 & 11.90 & 11.97 & 12.20 & 11.95 & 11.75 & 11.83 & 11.63 \\
\hline & $\pm 0.08^{a}$ & $\pm 0.09 a$ & $\pm 0.08^{a}$ & $\pm 0.11^{b}$ & $\pm 0.10^{\mathrm{a}}$ & $\pm 0.09 \mathrm{a}$ & $\pm 0.09^{b}$ & $\pm 0.10^{a}$ & $\pm 0.11^{\mathrm{ab}}$ \\
\hline \multirow[t]{2}{*}{ CM4 } & 11.30 & 11.40 & 11.38 & 11.40 & 11.60 & 11.63 & 11.43 & 11.48 & 11.18 \\
\hline & $\pm 0.08^{\text {cde }}$ & $\pm 0.09 b c$ & $\pm 0.08 \mathrm{bc}$ & $\pm 0.09^{c}$ & $\pm 0.12^{\mathrm{bc}}$ & $\pm 0.09 \mathrm{bc}$ & $\pm 0.09 \mathrm{~cd}$ & $\pm 0.10^{b c}$ & $\pm 0.11^{\mathrm{c}}$ \\
\hline \multirow[t]{2}{*}{ LBG $^{5}$} & 11.43 & 11.43 & 11.48 & 11.05 & 10.97 & 11.18 & 11.20 & 11.40 & 11.10 \\
\hline & $\pm 0.08^{\mathrm{bcd}}$ & $\pm 0.09 \mathrm{bc}$ & $\pm 0.08^{b}$ & $\pm 0.09^{d}$ & $\pm 0.12^{d}$ & $\pm 0.09 \mathrm{~d}$ & $\pm 0.09 \mathrm{~d}$ & $\pm 0.11^{b c}$ & $\pm 0.11^{\circ}$ \\
\hline \multirow[t]{2}{*}{ Guar gum } & 11.10 & 11.10 & 11.13 & 11.33 & 11.35 & 11.68 & 11.25 & 11.00 & 11.13 \\
\hline & $\pm 0.08^{\circ}$ & $\pm 0.09^{d}$ & $\pm 0.08^{c}$ & $\pm 0.09^{c}$ & $\pm 0.10^{\mathrm{cd}}$ & $\pm 0.09^{a b c}$ & $\pm 0.09^{d}$ & $\pm 0.10^{d}$ & $\pm 0.11^{c}$ \\
\hline \multirow[t]{2}{*}{ Gelatin } & 11.65 & 11.65 & 11.80 & 11.90 & 11.95 & 11.88 & 11.58 & 11.70 & 11.88 \\
\hline & $\pm 0.08^{a b}$ & $\pm 0.09 a b$ & $\pm 0.08^{a}$ & $\pm 0.09^{b}$ & $\pm 0.10^{a b}$ & $\pm 0.09 a b$ & $\pm 0.09 \mathrm{bc}$ & $\pm 0.10^{\mathrm{ab}}$ & $\pm 0.11^{a}$ \\
\hline \multirow[t]{2}{*}{ Control b } & 11.48 & 11.30 & 11.30 & 11.35 & 11.40 & 11.45 & 11.35 & 11.20 & 11.33 \\
\hline & $\pm 0.08^{b c d}$ & $\pm 0.09^{\mathrm{c}}$ & $\pm 0.08^{b c}$ & $\pm 0.09^{c}$ & $\pm 0.10^{\mathrm{cd}}$ & $\pm 0.09^{c}$ & $\pm 0.09^{c d}$ & $\pm 0.10^{\circ d}$ & $\pm 0.11^{\mathrm{bc}}$ \\
\hline
\end{tabular}


$\mathrm{pH}$ values are summarized in table $\mathrm{I}$. At $\mathrm{pH} \mathrm{1,} \mathrm{the} \mathrm{amounts} \mathrm{of} \mathrm{total,} \mathrm{soluble} \mathrm{and}$ ionic calcium are substantially the same for each hydrocolloid, indicating that the ions remained in solution rather than forming insoluble complexes with any of the polymers. At this $\mathrm{pH}$, the carboxyl or sulfate groups of the anionic hydrocolloids are protonated. At $\mathrm{pH} 4$ both ionic and soluble $\mathrm{Ca}$ levels decreased substantially in the presence of carrageenan and alginate, indicating that the polysaccharide functional groups became ionized, enabling them to interact with $\mathrm{Ca}$, with approximately 50 to $60 \%$ of the $\mathrm{Ca}$ forming insoluble complexes. The precipitation of more calcium by alginate than by carrageenan may be due to their different chemical structures: the alginate molecule consisting exclusively of mannuronic and guluronic acid units, whereas carrageenan is characterized by repeating units of 1,3 galactose sulfate and 1,4 linked 3,6 anhydro-D-galactose, ie fewer ionizable groups in the latter (Sand, 1982). Differences in $\mathrm{pK}$ may also partly explain the affinity of $\mathrm{Ca}$ with respect to these hydrocolloids.

Pectin, CMC, locust bean gum, guar gum and gelatin did not appear to have irreversibly bound $\mathrm{Ca}^{2+}$ at $\mathrm{pH} 4$, since no decrease in either ionic or soluble calcium levels was observed. Kohn (1975) has reported that addition of $1.5 \mathrm{mM} \mathrm{Ca}$ to pectin solutions led to the formation of strong intermolecular chelate bonds involving carboxyl groups. Rees (1982) has suggested an egg-box structure whereby calcium ions forming chelate bonds with oxygen atoms from both galacturonan chains fit into "cavities" in the structure.

As for CMC, in spite of the presence of carboxyl groups, the molecule did not affect soluble and ionic $\mathrm{Ca}$. This is probably due to the low CMC concentration used in this work. As reported by Glicksman (1982), at lower concentrations, this cellu- lose gum shows well-defined Newtonian behavior characterized by polymer chains which are widely separated, preventing thus interactions between $\mathrm{Ca}$ and opposite carboxyl groups. At pH 7, neither ionic calcium nor soluble calcium levels decreased in the presence of guar gum, locust bean gum, pectin, gelatin or CMC.

In the presence of carrageenan, the percentage of both amount of soluble and ionic $\mathrm{Ca}$ remained the same when the $\mathrm{pH}$ was increased from 4 to 7 . With alginate, both soluble and ionic $\mathrm{Ca}$ decreased to less than $80 \%$ of total $\mathrm{Ca}$ at neutral $\mathrm{pH}$. This may be due to a higher degree of change in the ionization of carboxyl groups as compared to the sulfate groups of carrageenan.

As shown in table II, at a hydrocolloid concentration of $0.4 \%$, all added calcium remained ionic at $\mathrm{pH} 1$. These results are similar to those observed for $0.2 \%$ hydrocolloid level at the same $\mathrm{pH}$. At $\mathrm{pH} 4$, however, carrageenan and alginate reduced soluble Ca levels by 72 and $44 \%$ respectively, while the other hydrocolloids did not precipitate. These reductions were more pronounced than those with $0.2 \%$ alginate or carrageenan since more ionic groups were involved at the higher concentration. It should be noted that soluble and ionic $\mathrm{Ca}$ were equivalent in both cases, indicating the absence of soluble Ca-alginate or $\mathrm{Ca}$-carrageenan complexes. With the $\mathrm{pH}$ increased to 7 , the amount of insoluble alginate-bound calcium decreased, approximately $89 \%$ of the total $\mathrm{Ca}$ remaining in the soluble state. The substantial difference between ionic and soluble $\mathrm{Ca}$ levels (ionic $\mathrm{Ca}$ level < soluble $\mathrm{Ca}$ level) suggests that alginate formed soluble complexes with calcium. The precipitation of less calcium by $0.4 \%$ alginate at neutral $\mathrm{pH}$ may be due to the formation of aggregates in which most ionized carboxyl groups of mannuronic segments were free; the $\mathrm{Ca}^{2+}$ 
Table II. Effects of $0.4 \%$ hydrocolloid solutions on soluble and ionic calcium at three $\mathrm{pH}$ levels. ${ }^{1}$ Total calcium; ${ }^{2}$ soluble calcium; ${ }^{3}$ ionic calcium; ${ }^{4}$ carboxymethylcellulose; ${ }^{5}$ locust bean gum; ${ }^{6} \mathrm{CaCl}_{2}$ without gum; ${ }^{a-f}$ different letters in superscript denote significant differences in each column $(P<0.05)$.

Effets de solutions d'hydrocolloides à $0,4 \%$ sur les teneurs en calcium soluble et ionique à trois niveaux de $\mathrm{pH}$.

\begin{tabular}{|c|c|c|c|c|c|c|c|c|c|}
\hline \multirow[b]{2}{*}{ Hydrocolloids } & \multicolumn{3}{|c|}{$\mathrm{pH} 1$} & \multicolumn{3}{|c|}{$\mathrm{pH} 4$} & \multicolumn{3}{|c|}{$\mathrm{pH} 7$} \\
\hline & $\mathrm{Ca}_{\text {tot }}{ }^{1}$ & $\begin{array}{l}\mathrm{Ca}_{\text {sol }}{ }^{2} \\
\text { (ppm) }\end{array}$ & $\mathrm{Ca}_{\text {ion }}{ }^{3}$ & $\mathrm{Ca}_{\text {tot }}$ & $\begin{array}{l}\mathrm{Ca}_{\text {sol }} \\
(\mathrm{ppm})\end{array}$ & $\mathrm{Ca}_{\text {ion }}$ & $\mathrm{Ca}_{\text {iot }}$ & $\begin{array}{l}\mathrm{Ca}_{\text {sol }} \\
(\mathrm{ppm})\end{array}$ & $\mathrm{Ca}_{\text {ion }}$ \\
\hline K-carrageenan & $\begin{array}{l}11.33 \\
\pm 0.09 \propto d\end{array}$ & $\begin{array}{l}11.40 \\
\pm 0.07 \text { cd }\end{array}$ & $\begin{array}{l}11.68 \\
\pm 0.07 \mathrm{~b}\end{array}$ & $\begin{array}{l}11.20 \\
\pm 0.09 \mathrm{e}\end{array}$ & $\begin{array}{c}3.10 \\
\pm 0.11^{\mathrm{d}}\end{array}$ & $\begin{array}{c}2.83 \\
\pm 0.12^{\circ}\end{array}$ & $\begin{array}{l}12.37 \\
\pm 0.15 a\end{array}$ & $\begin{array}{c}5.32 \\
\pm 0.09^{\circ}\end{array}$ & $\begin{array}{r}5.35 \\
\pm 0.19^{\circ}\end{array}$ \\
\hline Alginate & $\begin{array}{l}11.53 \\
\pm 0.09 \mathrm{bc}\end{array}$ & $\begin{array}{l}11.63 \\
\pm 0.07 \mathrm{bc}\end{array}$ & $\begin{array}{l}11.50 \\
\pm 0.07 \mathrm{~b}\end{array}$ & $\begin{array}{l}11.63 \\
\pm 0.01^{c}\end{array}$ & $\begin{array}{c}5.10 \\
\pm 0.11^{\mathrm{c}}\end{array}$ & $\begin{aligned} & 5.30 \\
\pm & 0.12^{\mathrm{d}}\end{aligned}$ & $\begin{array}{l}11.55 \\
\pm 0.09^{c}\end{array}$ & $\begin{array}{r}10.33 \\
\pm 0.11^{d}\end{array}$ & $\begin{array}{c}8.48 \\
\pm 0.11^{\mathrm{d}}\end{array}$ \\
\hline Pectin & $\begin{array}{l}12.23 \\
\pm 0.09^{a}\end{array}$ & $\begin{array}{l}12.18 \\
\pm 0.07^{a}\end{array}$ & $\begin{array}{l}12.38 \\
\pm 0.07^{a}\end{array}$ & $\begin{array}{l}12.33 \\
\pm 0.09 a\end{array}$ & $\begin{array}{l}12.45 \\
\pm 0.11^{a}\end{array}$ & $\begin{array}{l}12.25 \\
\pm 0.12^{\mathrm{a}}\end{array}$ & $\begin{array}{l}12.30 \\
\pm 0.09^{a b}\end{array}$ & $\begin{array}{l}12.10 \\
\pm 0.11^{\mathrm{a}}\end{array}$ & $\begin{array}{l}11.30 \\
\pm 0.11^{b}\end{array}$ \\
\hline $\mathrm{CM}^{4}$ & $\begin{array}{l}11.08 \\
\pm 0.09 \mathrm{~d}\end{array}$ & $\begin{array}{l}11.13 \\
\pm 0.070\end{array}$ & $\begin{array}{l}11.13 \\
\pm 0.07 \mathrm{~cd}\end{array}$ & $\begin{array}{l}11.23 \\
\pm 0.04^{\ominus}\end{array}$ & $\begin{array}{l}11.38 \\
\pm 0.11 \mathrm{~b}\end{array}$ & $\begin{array}{l}11.00 \\
\pm 0.12^{\mathrm{c}}\end{array}$ & $\begin{array}{l}11.35 \\
\pm 0.09 \text { cd }\end{array}$ & $\begin{array}{l}11.15 \\
\pm 0.11^{b c}\end{array}$ & $\begin{array}{r}9.80 \\
\pm 0.11^{\mathrm{c}}\end{array}$ \\
\hline $\mathrm{LBG}^{5}$ & $\begin{array}{l}11.18 \\
\pm 0.09^{d}\end{array}$ & $\begin{array}{l}11.23 \\
\pm 0.07^{d \theta}\end{array}$ & $\begin{array}{l}11.30 \\
\pm 0.07^{e}\end{array}$ & $\begin{array}{l}11.35 \\
\pm 0.09 \text { de }\end{array}$ & $\begin{array}{l}11.28 \\
\pm 0.11^{\mathrm{b}}\end{array}$ & $\begin{array}{l}11.30 \\
\pm 0.12^{\mathrm{bc}}\end{array}$ & $\begin{array}{l}11.50 \\
\pm 0.09^{c}\end{array}$ & $\begin{array}{l}11.15 \\
\pm 0.11^{b c}\end{array}$ & $\begin{array}{l}11.28 \\
\pm 0.11^{\mathrm{b}}\end{array}$ \\
\hline Guar gum & $\begin{array}{l}11.18 \\
\pm 0.09^{d}\end{array}$ & $\begin{array}{l}11.13 \\
\pm 0.07^{e}\end{array}$ & $\begin{array}{l}11.05 \\
\pm 0.07^{d}\end{array}$ & $\begin{array}{l}11.55 \\
\pm 0.09 \text { cd }\end{array}$ & $\begin{array}{l}11.38 \\
\pm 0.11^{\mathrm{b}}\end{array}$ & $\begin{array}{l}11.48 \\
\pm 0.12^{\mathrm{b}}\end{array}$ & $\begin{array}{l}11.43 \\
\pm 0.09^{c}\end{array}$ & $\begin{array}{l}11.33 \\
\pm 0.11^{b}\end{array}$ & $\begin{array}{l}11.28 \\
\pm 0.11^{\mathrm{b}}\end{array}$ \\
\hline Gelatin & $\begin{array}{l}11.73^{b} \\
\pm 0.09^{b}\end{array}$ & $\begin{array}{l}11.70 \\
\pm 0.07 \mathrm{~b}\end{array}$ & $\begin{array}{l}11.63 \\
\pm 0.07^{\mathrm{b}}\end{array}$ & $\begin{array}{l}12.05 \\
\pm 0.09 \mathrm{~b}\end{array}$ & $\begin{array}{l}12.15 \\
\pm 0.11^{\mathrm{a}}\end{array}$ & $\begin{array}{l}11.90 \\
\pm 0.12^{\mathrm{a}}\end{array}$ & $\begin{array}{l}12.03 \\
\pm 0.09^{b}\end{array}$ & $\begin{array}{l}11.98 \\
\pm 0.11^{\mathrm{a}}\end{array}$ & $\begin{array}{l}12.28 \\
\pm 0.11^{a}\end{array}$ \\
\hline Control & $\begin{array}{l}11.28^{\mathrm{b}} \\
\pm 0.09^{\mathrm{d}}\end{array}$ & $\begin{array}{l}11.28 \\
\pm 0.07 \mathrm{de}\end{array}$ & $\begin{array}{l}11.25 \\
\pm 0.07 \text { cd }\end{array}$ & $\begin{array}{l}11.18 \\
\pm 0.09^{\mathrm{e}}\end{array}$ & $\begin{array}{l}11.10 \\
\pm 0.11^{\mathrm{b}}\end{array}$ & $\begin{array}{l}11.28 \\
\pm 0.12^{\mathrm{bc}}\end{array}$ & $\begin{array}{l}11.08 \\
\pm 0.09^{d}\end{array}$ & $\begin{array}{l}10.98 \\
\pm 0.11^{\mathrm{c}}\end{array}$ & $\begin{array}{l}11.15 \\
\pm 0.11^{\mathrm{b}}\end{array}$ \\
\hline
\end{tabular}

bonding sites for gelation with alginate occurring primarily on the guluronic segments (Sand, 1982). Increasing alginate or carrageenan concentrations had different effects on $\mathrm{Ca}$ solubility at $\mathrm{pH}$ 7. At a concentration of $0.4 \%$, carrageenan precipitated with $\mathrm{Ca}$ to a much greater extent than alginate did, whereas at the $0.2 \%$ level, alginate caused a much greater drop in the soluble $\mathrm{Ca}$ level than did carrageenan. Moreover, at $\mathrm{pH} 7$, pectin and $\mathrm{CMC}$ reduced ionic $\mathrm{Ca}$ levels by 15 and $10 \%$ respectively, indicating the formation of stable soluble complexes, while locust bean gum, gelatin and guar gum did not react with $\mathrm{Ca}$.

Results obtained with 0.2 and $0.4 \%$ hydrocolloid levels following stepped $\mathrm{pH}$ changes from 1 to 4 and 7 are illustrated in table III. Carrageenan, pectin, guar gum, and gelatin did not precipitate calcium at either the 0.2 or the $0.4 \%$ level. As compared to results shown in tables I and II, carrageenan did not precipitate $\mathrm{Ca}$ when the $\mathrm{pH}$ was sequentially raised from 1 to 7 . This may be due to differences in ionic strength of the reaction media corresponding to single and sequential $\mathrm{pH}$ treatments. Depolymerization of this hydrocolloid is also known to occur in acidic solutions (Black et al, 1965). Alginate, on the other hand, reduced both soluble $\mathrm{Ca}$ and ionic Ca levels approximately by $55 \%$, suggesting that most complexes formed were insoluble. These results are similar to those obtained in tables $\mathrm{I}$ and II at various $\mathrm{pHs}$. 
Table III. Effects of $0.2 \%$ and $0.4 \%$ hydrocolloid solutions on soluble and ionic calcium following sequential $\mathrm{pH}$ treatment ( $\mathrm{pH} 14 \quad 4$ ). ${ }^{1}$ Total calcium; ${ }^{2}$ soluble calcium; ${ }^{3}$ ionic calcium; ${ }^{4}$ carboxymethylcellulose; ${ }^{5}$ locust bean gum; ${ }^{6} \mathrm{CaCl}_{2}$ without gum; ${ }^{a-t}$ different letters in superscript denote significant differences in each column $(P<0.05)$.

Effets de solutions d'hydrocolloides à $0,2 \%$ et $0,4 \%$ sur les teneurs en calcium soluble et ionique après traitement séquentiel $\mathrm{du} \mathrm{pH}$.

\begin{tabular}{|c|c|c|c|c|c|c|}
\hline \multirow[b]{2}{*}{ Hydrocolloids } & \multicolumn{3}{|c|}{$0.2 \%$ hydrocolloid } & \multicolumn{3}{|c|}{$0.4 \%$ hydrocolloid } \\
\hline & $C a_{\text {tot }}{ }^{1}$ & $\begin{array}{l}C a_{s o}{ }^{2} \\
(p p m)\end{array}$ & $\mathrm{Ca}_{\text {ion }}{ }^{3}$ & $C a_{\text {tot }}$ & $\begin{array}{l}\mathrm{Ca}_{\text {sol }} \\
(\mathrm{ppm})\end{array}$ & $C a_{\text {ion }}$ \\
\hline \multirow[t]{2}{*}{ K-carrageenan } & 11.55 & 11.65 & 12.05 & 11.55 & 11.55 & 12.03 \\
\hline & $\pm 0.07^{c}$ & $\pm 0.08^{c d}$ & $\pm 0.11 \mathrm{a}$ & $\pm 0.15^{b}$ & $\pm 0.09^{b}$ & $\pm 0.07^{b}$ \\
\hline \multirow[t]{2}{*}{ Alginate } & 11.75 & 6.53 & 6.55 & 11.83 & 5.90 & 6.00 \\
\hline & $\pm 0.07 b c$ & $\pm 0.08^{\theta}$ & $\pm 0.11^{f}$ & $\pm 0.15^{b}$ & $\pm 0.09^{d}$ & $\pm 0.07^{f}$ \\
\hline \multirow[t]{2}{*}{ Pectin } & 12.00 & 12.05 & 12.03 & 12.55 & 12.40 & 12.68 \\
\hline & $\pm 0.07^{a}$ & $\pm 0.08 \mathrm{ab}$ & $\pm 0.11 \mathrm{ab}$ & $\pm 0.15^{a}$ & $\pm 0.09^{a}$ & $\pm 0.07^{a}$ \\
\hline \multirow[t]{2}{*}{$\mathrm{CMC}^{4}$} & 11.48 & 11.60 & 10.23 & 11.50 & 11.48 & 10.00 \\
\hline & $\pm 0.07^{d}$ & $\pm 0.08^{d}$ & $\pm 0.11^{\circ}$ & $\pm 0.15^{b}$ & $\pm 0.09^{b}$ & $\pm 0.07^{\circ}$ \\
\hline \multirow[t]{2}{*}{ LBG $^{5}$} & 11.53 & 11.68 & 11.40 & 11.53 & 11.58 & 11.73 \\
\hline & $\pm 0.07^{\mathrm{cd}}$ & $\pm 0.08^{c d}$ & $\pm 0.11^{d}$ & $\pm 0.15^{b}$ & $\pm 0.09^{b}$ & $\pm 0.07^{c}$ \\
\hline \multirow[t]{2}{*}{ Guar gum } & 11.78 & 11.85 & 11.70 & 11.50 & 11.30 & 11.38 \\
\hline & $\pm 0.07^{b}$ & $\pm 0.08^{b c}$ & $\pm 0.11^{\mathrm{bcd}}$ & $\pm 0.15^{b}$ & $\pm 0.09 \mathrm{bc}$ & $\pm 0.07^{d}$ \\
\hline \multirow[t]{2}{*}{ Gelatin } & 11.75 & 12.10 & 11.78 & 12.45 & 12.53 & 12.78 \\
\hline & $\pm 0.07^{b c}$ & $\pm 0.08^{a}$ & $\pm 0.11 \mathrm{abc}$ & $\pm 0.15^{a}$ & $\pm 0.09^{a}$ & $\pm 0.07^{a}$ \\
\hline \multirow[t]{2}{*}{ Control b } & 11.53 & 11.45 & 11.50 & 11.55 & 11.18 & 11.48 \\
\hline & $\pm 0.07^{c d}$ & $\pm 0.08^{d}$ & $\pm 0.11^{\mathrm{cd}}$ & $\pm 0.15^{b}$ & $\pm 0.09^{c}$ & $\pm 0.07^{d}$ \\
\hline
\end{tabular}

As for $\mathrm{CMC}$, soluble complexes were formed with ionic $\mathrm{Ca}$ level being decreased slightly by $11 \%$.

The results of this investigation clearly indicate that the $\mathrm{Ca}$ binding capacities of the hydrocolloids studied were dependent upon parameters such as the type and concentration of hydrocolloid, on $\mathrm{pH}$ and on ionic strength. Gelatin, locust bean gum and guar gum, which are neutral polymers, did not precipitate with calcium. This is consistent with the observations of Harmuth-Hoene and Schelenz (1980) who reported that neither of the latter two gums affected $\mathrm{Ca}$ absorption in growing rats. In spite of their anionic character, pectin, CMC, alginate and carrageenan differ in their ability to bind calcium during stepped $\mathrm{pH}$ changes. Only alginate was found to bind appreciable amounts of $\mathrm{Ca}$ ions in an insoluble form, while pectin, carrageenan and CMC had no effect on Ca solubility. Calcium may therefore be less available in the presence of alginate.

\section{REFERENCES}

Albanese AA (1977) Bone loss: causes, detections and therapy. In: Current Topics in Nutrition and Disease (Albanese AA, ed), Alan R Liss Inc, New York

Allen LH (1982) Calcium bioavailability and absorption. A review. Am J Clin Nutr 35, 783808 
Bagheri S, Guéguen L (1985) Effect of wheat bran and pectin on the absorption and retention of phosphorus, calcium, magnesium and zinc by the growing pig. Reprod Nutr Develop 25, 705-716

Berner LA, Hood LF (1983) Iron binding by sodium alginate. $J$ Food Sci 48, 755-758

Black WAP, Blackmore RR, Colquhoun JA, Dewar ET (1965) The evaluation of some red marine algae as a source of carrageenan and its kappa- and lambda- components. J Sci Food Agric 16, 573-585

Camire AL, Clydesdale FM (1981) Effect of pH and heat treatment on the binding of $\mathrm{Ca}, \mathrm{Mg}$, $\mathrm{Zn}$ and $\mathrm{Fe}$ to wheat bran and fractions of dietary fiber. J Food Sci 46, 548-551

Carr TEF, Harrison GE, Hemphreys ER, Sutton A (1968) Reduction in the absorption and retention of dietary strontium in man by alginate. Int J Radiat Biol 14, 225-233

Glicksman M (1982) Functional properties of hydrocolloids. In: Food Hydrocolloids (Glicksman $M$, ed) CRC Press Inc, Boca Raton, Florida, 47-99

Harmuth-Hoene AL, Schelenz R (1980) Effect of dietary fiber on mineral absorption in growing rats. J Nutr 110, 1774-1784

Heaney RP (1982) Calcium intake requirement and bone mass in the elderly. J Lab Clin Med $100,309-312$

Hodgkinson A, Nordin BED, Hambleton J, Oxby CB (1967) Radiostronstrium absorption in man: suppression by calcium and by sodium alginate. Can Med Assoc J 97, 11391143

Kim H, Zemel MB (1986) In vitro estimation of the potential bioavailability of calcium from sea mustard (Undaria pinnatifidia), milk, and spinach under simulated normal and reduced gastric acid conditions. J Food Sci 51, 957959

Kohn R (1975) lon binding on polyuronatesalginate and pectin. Pure Appl Chem 42, 371-397

Matkovic V, Kostial K, Simonivoc I (1979) Bone status and fracture rates in two regions of $\mathrm{Yu}$ goslavia. Am J Clin Nutr 32, 540-549
McCarron DA (1985) Is calcium more important than sodium in the pathogenesis of essential hypertension? Hypertension 7, 607-627

Miller DD, Schricker BR, Rassmussen RR, Van Campen D (1981) An in vitro method for estimation of iron availability from meals. $A m J$ Clin Nutr 34, 2248-2256

Millis J, Reed FB (1947) The effect of sodium alginate on absorption of calcium. Biochem $J$ 41, 273-275

Rees DA (1982) Polysaccharide conformation in solutions and gels-recent results on pectin. Carbohydr Polym 2, 254-263

Rizzotti R, Tilly G, Patterson RA (1983) The use of hydrocolloids in the dairy industry. In: Gums and Stabilisers for the Food Industry (Phillips GO, Wedlock DJ, Williams PA, eds) Pergamon Press, New York, 285-293

Sand R (1982) Nomenclature and structure of carbohydrate hydrocolloids. In: Food Hydrocolloids (Glicksman M, ed) CRC Press Inc, Boca Raton, Florida, 19-46

SAS (1986) SAS User's Guide. SAS Institute, Inc, Cary, North Carolina

Sowers MR, Wallace RB, Lemke JM (1985) Blood pressure and vitamin D. Am J Clin Nutr $42,135-142$

Viola S, Zimmermann G, Mokady S (1970) Effect of pectin and algin upon protein utilization, digestibility of nutrients and energy in young rats. Nutr Rep Int 1, 367-375

Wien EM, Schwarz R (1985) Dietary calcium exchangeability and bioavailability. Evaluation and potential uses of an in vitro digestion procedure. In: Nutritional Bioavailability of Calcium (Kies C, ed) American Chemical Society, Washington, DC, 1-16

Zemel MB (1984) In vitro evaluation of the effects of ortho-tripoly- and hexametaphosphate on zinc, iron and calcium bioavailability. J Food Sci 49, 1562-1565

Zemel MB, Zemel PC (1985) Effects of food gums on zinc and iron solubility following in vitro digestion. J Food Sci 50, 547-550 